\title{
Małgorzata Jakubowska
}

Uniwersytet Łódzki

Instytut Kultury Współczesnej

\section{Alicja w krainie słów i obrazów}

Alicja wpadła!' Alicja wpadła do króliczej nory i tak rozpoczęła się jej przygoda w Krainie Czarów na kartach opowieści Lewisa Carrolla. Wpadła także w kulturowy obieg „prze-pisywanych” tekstów. U podstaw fascynacji tym utworem leży niewątpliwie jego wieloznaczność. Na samej powierzchni tekstu znajdziemy prześmiewczy obraz wiktoriańskiej epoki, powieść „pedagokomiczną” ukazującą absurdalne formy dawnej edukacji i angielski humor, który odsłania śmieszność świata dorosłych. Głębiej gloryfikację dzieciństwa, ale szczególnie rozumianego - jako kraina wolnej wyobraźni, rozpięta między marzeniem a jawą. Dla dzieci wonderland pozostaje inspiracją do zabawy i fantazjowania, jednocześnie uczy myślenia: zadawania pytań i szukania odpowiedzi, podstaw logiki. Dorosłym natomiast przypomina o potrzebie wolności, uświadamia, że nasza wyobraźnia i marzenia są ograniczane i kontrolowane przez społeczne reguły oraz konwenanse - jesteśmy zniewoleni logiką konsekwencji i zdrowym rozsądkiem, nie tylko w życiu, ale także w najskrytszych fantazjach.

Jednak chyba najbardziej fascynująca w tej krainie pozostaje relacja między nonsensem a sensem. Nie tylko dlatego, że wszystko się tu może zdarzyć. W fantazyjnym świecie Carrolla nonsens nie jest przeciwstawiony sensowi jako jego opozycja. Przeciwieństwem sensu okazuje się komunał - oczywista, trywialna „prawda”, powtarzana bezrefleksyjnie. A słowa ukazują często swoje drugie dno, jakby kpiły z tych, którzy używają ich tylko „na serio”. Zdanie bogate w sens zaprasza do myślenia, domaga się namysłu, a zdanie-banał zabija myślenie. Na tym tle absurd, nonsens ukazuje swoje szczególne właściwości. Zawiera coś, co nie podlega jednoznacznym rozstrzygnięciom, coś, co wchodzi w konflikt z naszym rozumem i regułami

${ }^{1}$ Nawiązuję pierwszym zdaniem artykułu do szkicu Tomasza Marciniaka, Alicja wpadta, http://magazyn.o.pl/2013/tomasz-marciniak-alicja-wpadla-o-kulturowych-losach-i-zapozyczeniach-ze-slynnej-powiesci-lewis-carroll-rita-baum/ O kulturowych losach i zapożyczeniach z opowieści Lewisa Carrolla [dostęp 23.11.2013]. 
logiki. Dzięki temu inicjuje ruch sensotwórczy - już nie zaprasza, ale zmusza do myślenia - musimy znaleźć rozwiązanie niemożliwego paradoksu. W powieści możemy zatem odnaleźć tezy analogiczne $\mathrm{w}$ wielu punktach do tych z Logiki sensu Gillesa Deleuze'a, tyle że u Carolla pojawiają się z finezyjną lekkością bajkowej opowieści, a nie zakręconych wywodów postmodernistycznej filozofii.

\section{Alicja w krainie słów}

Roland Topor proponuje własne spojrzenie na Alicję $w$ krainie liter ${ }^{2}$. Przewrotna treść tej małej książeczki stworzonej przez pisarza-rysownika pozostaje hołdem dla Carrolla. Tym razem Alicja, zasypiając nad lekturą, znalazła się po drugiej stronie kartki, wśród liter, z których każda ma osobowość i własny życiorys. Nic dziwnego! Utwór angielskiego bajarza stał się źródłem inspiracji dla wszystkich artystów, którzy mają skłonność do pur nonsensu, czarnego humoru, surrealistycznych dowcipów i pielęgnują poczucie absurdu świata, w którym jest „Coraz zaskakującej!”, jak niegdyś wykrzyknęła Alicja, zapominając „poprawnego języka w buzi”.

Na poziomie lingwistycznym pisarstwo Carrolla stawia duże wymagania wszelkim przekładom na inny język. Wprowadzone gry i zabawy słowne często nie poddają się tłumaczeniom filologicznym, co skłania do szukania różnych rozwiązań lingwistycznych i powoduje powstawanie wielu wersji; w języku polskim przekładów było kilkanaście . Nawet imiona

${ }^{2}$ R. Topor, Alicja $w$ Krainie Liter. O tym, co Alicja odkryła po drugiej stronie kartki, przeł. A. Taborska, Warszawa-Gdańsk 2001.

${ }^{3}$ L. Carroll, Alicja w Krainie Czarów, przeł. J. Kozak, Warszawa 1999, s. 21.

${ }^{4}$ Najważniejsze przekłady na język polski: Przygody Alinki w krainie cudów (1910) - pierwsze tłumaczenie Adela S. (nie jest znane pełne nazwisko tłumaczki), Ala w krainie czarów (1927) - przeł. M. Morawska (wolne tłumaczenie; wiersze, przełożone przez znanego tłumacza i poetę Antoniego Lange), $W$ zwierciadlanym domu. Powieść dla mtodzieży (1936) - przeł. J. Zawisza-Krasucka (pierwsze polskie tłumaczenie drugiego tomu przygód Alicji, Through the Looping-Glass), Alicja w krainie czarów (1955) - przeł. A. Marianowicz (odbiega od oryginalnego tekstu, szczególnie dotyczy to wierszy), Przygody Alicji w Krainie Czarów i O tym, co Alicja odkryła po drugiej stronie Lustra (1965) - M. Słomczyński (pierwszy przekład zgodny z oryginałem), Alicja w krainie czarów i Po drugiej stronie Lustra (1986) - przeł. R. Stiller, Alicja w Krainie Czarów Alicja po drugiej stronie Lustra (1999) - J. Kozak (uwspółcześniony język utworu). Kolejni tłumacze to: K. Dworak (2010), B. Kaniewska (2010), M. Machay (2010), E. Tabakowska (2012). Należy przy tym pamiętać, iż oprócz przekładów oryginalnych tekstów pojawiały się również tłumaczenia różnego rodzaju adaptacji: list dialogowych z filmów, komiksów, ale także skróconych, uproszczonych wersji dla młodszych dzieci, różnych rysowanek-wyliczanek, które często pojawiały się w polskiej wersji językowej, ale korzystały z tłumaczeń-adaptacji francuskich czy włoskich. 
bohaterów zachęcają do różnych skojarzeń i tworzenia rozmaitych ekwiwalentów. Gdy uśmiechniętego Kota z Cheshire potraktujemy jako odwołanie do angielskiego idiomu to grin like a Cheshire Cat, potrzebny jest przypis wyjaśniający źródłosłów, ale urealniona metafora w przekładzie Jolanty Kozak po polsku oznacza: „szczerzyć się jak głupi do sera”. Dzięki temu zrozumiemy, iż kot Księżnej „szczerzy się” dlatego, że jest Szczerym Kociskiem. Inny bohater: Szalony Kapelusznik - u Słomczyńskiego „tłumaczy się" historycznym wyjaśnieniem: rtęć używana podczas filcowania materiału na kapelusze zatruwała organizm kapeluszników, wywołując napady niepoczytalności. Kozak natomiast proponuje tu inne imię: Bezdenny Kapelusznik, ponieważ szyje on kapelusze bez dna, zostaje skojarzony $\mathrm{z}$ rodzimym wyrażeniem o bezdennej głupocie. Imiona postaci to zaledwie wierzchołek góry lodowej. W oryginalnym tekście wyzwań translatorskich jest wiele, ba, każde zdanie domaga się pedantycznej uwagi. Między słowami i zdaniami Carrolla odnajdziemy parodię, pastisz, intertekstualne odniesienia do dziecięcych wierszyków i piosenek, ale także do literatury poważnej, historii i obyczajowości Anglii. Czy tłumacz powinien być pietystą, jak Maciej Słomczyński, i kosztem archaizacji zachować wierność wobec oryginału, skrupulatnie oddając wiktoriańską obyczajowość? Czy lepsza jest strategia Roberta Stillera - tekstologa, który zachowuje ekwiwalencję formalną, adresując książkę Carrolla raczej do dziecka tkwiącego w dorosłym? A może za najlepszy uznamy przekład „hermeneutyczny” proponowany przez Jolantę Kozak, która wykorzystuje rodzime skojarzenia i gry językowe, zachęcając przede wszystkim dziecięcego czytelnika do śmiechu i zabawy? ${ }^{5}$ Odmienne metody i założenia przyjęte w translacji powodują istotne różnice w przekładach Alicji w krainie czarów.

Carroll zasłynął także jako twórca wyrazów-walizek, do których pakował znaczenia dwóch lub kilku słów ${ }^{6}$. Nonsens, jaki proponuje, to nie chaos znaczeniowy ani wyrazy niedorzeczne. Wręcz odwrotnie: technika słowotwórcza

${ }^{5}$ Szczegółowo bada te trzy wymienione strategie translatorskie E. Rajewska, bogato ilustrując swoje rozważania przykładami (zob. tejże, Dwie wiktoriańskie chwile $w$ Troi, trzy strategie translatorskie: „Alice's Adventures in Wonderland” $i$ „Through the Looking-Glass" Lewisa Carrolla w przekładach Macieja Stomczyńskiego, Roberta Stillera i Jolanty Kozak, Poznań 2004, s. 49-70).

${ }^{6}$ L. Carroll (The Hunting of the Snark, s. 48. Cyt. za: E. Rajewska, Nonsens peten sensu - „Jabberwocky” Lewisa Carrola, [w:] Od Carrolla do Norwida, wybór i oprac. J. Borowczyk, Z. Przychodniak, P. Śliwiński, Poznań 2003, s. 55) tak wyjaśniał swoją metodę słowotwórczą: „Weź dwa słowa, przykładowo: fuming [wściekły] i furious [rozjuszony]. Pomyśl, że wypowiesz je oba, ale nie podejmuj decyzji, które z nich powiesz najpierw. Następnie otwórz usta i dobądź głosu. Jeżeli twoje myśli skłaniały się choć troszeczkę w stronę fuming, powiesz fuming-furious; jeżeli zaś choćby o szerokość włosa były bliższe furious, powiesz furious-fuming; jeżeli jednak posiadasz najrzadszy z darów, perfekcyjnie zrównoważony umysł, powiesz frumious". 
obdarza wybrane słowa znaczeniem podwójnym lub wielokrotnym. Oczywiście złożenia słowne: „wściekłorozjuszony” czy „szorstkogrubiańskowzburzony” w tłumaczeniu filologicznym nie oddają całej frajdy językowych skojarzeń. Zabawa zaczyna się, gdy jest „smaszno” - jak pisze Słomczyński (czyli ni to straszno, ni to śmieszno) - a „miecz migbłystalny świstotnie” w najbardziej dramatycznym momencie walki. Nie dziwi, że bohater po zgładzeniu potwora „śmieselił się rad w głos”. Jedynie w bardzo pobieżnej lekturze „upakowane" słowa Carrolla można potraktować jako bezład semantyczny. Neologizmy pulsują różnorodnym znaczeniem i brzmieniem, prowokują zaskakujące skojarzenia. Jabberwocky - nonsensowna ballada zamieszczona w drugim tomie przygód małej bohaterki oraz późniejszy utwór The Hunting of the Snark (Wyprawa na żmirłacza w przekładzie Roberta Stillera; tajemniczy potwór, w oryginale snark, jest hybrydą węża - snake i rekina - smark, co w polszczyźnie zostało wyrażone przez skrzyżowanie żmii z żarłaczem) stały się ukoronowaniem lingwistycznej metody Carrolla.

Czy może zatem dziwić, iż twórczość Carrolla wciąż jest „prze-pisywana" w kolejnych tłumaczeniach? Sam Dżabbersmok stał się inspiracją komedii Terry'ego Gilliama z ekipy Monty Pytona. Przekład Macieja Słomczyńskiego znalazł się w polskiej wersji filmu. Alicja inspiruje także pisarzy. Odwołań, cytatów, nawiązań choćby w kreowaniu poetyki snu było wiele, ale warto wspomnieć te najbardziej wyraziste czy po prostu moje ulubione. W Alicję i świat po drugiej stronie lustra zapatrzył się nie tylko Roland Topor, ale także James Joyce, co wyraźnie widać w Finneganów trenie, gdzie pisarz wykorzystuje Carrollowskie gry lingwistyczne, łącząc nie tylko słowa o różnych znaczeniach, ale także pochodzące z różnych języków ${ }^{8}$. Norweski autor Jostein Gaarder zaproponował przejmującą opowieść $W$ zwierciadle, niejasno, w której umierająca dziewczynka rozmawia z aniołem ${ }^{9}$. Kiedy przychodzimy na świat, dostajemy cały świat w prezencie, ale my - ludzie jesteśmy niczym bańki mydlane, chociaż pojawiamy się na chwilę, zapominamy szybko, jak zaskakujący jest sam fakt naszego istnienia. Widzimy świat tylko w zwierciadle i niejasno. Gdy już przejdziemy na drugą stronę lustra, wszystko się wyjaśni - obiecuje anioł - zobaczymy wyraźnie, zrozumiemy, tylko... nie będziemy już widzieć siebie, nie będziemy odczuwać, smakować, dotykać.

W polskiej literaturze także pojawiło się kilka bardzo ciekawych przykładów na renarracje wątków z Alicji w Krainie Czarów. Na uwagę zasługuje dedykowana „Byłym Dzieciom” książka Zbigniewa Batki $Z$ powrotem

${ }^{7}$ Przymiotnik uffish oznacza stan umysłu, gdy głos staje się gruffish - szorstki, zachowanie rouglish - grubiańskie, a usposobienie huffish - wzburzone wyjaśniał Carroll w liście do małej przyjaciółki. Por. E. Rajewska, Nonsens pełen sensu..., s. 70.

8 Zob. J. Joyce, Anna Livia Plurabelle, przeł. M. Słomczyński, Kraków 1985.

${ }^{9}$ J. Gaarder, W zwierciadle, niejasno, przeł. I. Zimnicka, Warszawa 1998. 
czyli fatalne skutki niewłaściwych lektur ${ }^{10}$. Zadziwiająca jest to opowieśćc ${ }^{11}$. Pisana pod prąd czasów. Z tęsknotą za światem fantazji i umykającej przeszłości. Opowieść nasycona melancholią, bo świat dzieciństwa odszedł, ale czy bezpowrotnie? Prolog ewidentnie nawiązuje do powieści Carrolla. Opis wyprawy łódką, choć przypomina sportową rywalizację, podkreśla znużenie bohatera, zarówno samą wycieczką, jak i towarzystwem, które nie zauważa koszmarnego zgiełku i „wyścigu szczurów”, w którym wszyscy biorą udział. Finał wycieczki, choć znany i niekwestionowany przez narratora, w opowieści Batki przestaje być celem, do którego należy gonić w pośpiechu. Okazuje się bowiem, że strumień może popłynąć z powrotem: „Czyli od morza do źródła. W dodatku wystarczyło zamoczyć w nim nogę, by zostać nieuchronnie porwanym przez falę wspomnien" ${ }^{12}$. Pojawiają się także inne wątki wysnute z krainy czarów, jakby w odbiciach, trochę podobne, a trochę przekształcone czy odwrócone. Dominuje atmosfera sennych marzeń. W tej aurze dziwne sploty zdarzeń nikogo nie zaskakują, podobne jak swobodne nawiązania do różnych bajkowych wątków i postaci. Nerwowe spoglądanie na zegarek przestaje być atrybutem Królika, który zamiast spieszyć się, szuka innego, powolnego rytmu czasu. Ze względu na kolor sierści jest Mysim Królikiem, a gdy futro zjedzą mu mole, zrozumiemy, że jest też Nieborakiem, który swoją wstydliwą nagość przysłania znalezioną na dnie szafy mufką. Alicja także pojawia się w tej książce, bardziej jako wspomnienie, które ogniskuje różne bajkowe tropy. To ukochana wnuczka Babci, tyle że Babcia okazuje się hersztem bandy 40 rozbójników, który preferuje walkę włóczką i drutami zamiast ręcznych robótek, do których zwykle służą. Idea przyświecająca rzezimieszkom z opowieści Batki również posiada korzenie w bajkowej, utopijnej wizji. Chcą odbierać bogatym, a dawać biednym, co odczytać można jako skrzyżowanie postawy Robin Hooda i prześmiewczo potraktowanego... komunizmu. Rozbójnicy zabierają złote talary Królikowi i Koniowi, ale gdy podróżnicy stają się biedni, dobrzy zbóje „idą po rozum do głowy”: muszą im teraz przekazać jakieś bogactwo, skoro chcą wspomagać ubogich. Gdy Królik i Koń znów są w posiadaniu złota, ponownie trzeba na nich napaść... i tak zabawa w zabieranie i rozdawanie może trwać bez końca.

I chociaż słowa-walizki nie pojawiają się w tym tekście, trzeba przyznać, iż Zbyszek Batko, skądinąd znakomity tłumacz literatury, posługuje się barwnym, pełnym nieoczekiwanych skojarzeń językiem. Proponuje zaskakujące kalambury i gry stylistyczne, bawi się związkami frazeologicznymi,

${ }^{10}$ Z. Batko, Z powrotem czyli fatalne skutki niewłaściwych lektur, Łódź 1993.

${ }^{11}$ Zob. T. Marciniak, Alicja wpadta! O kulturowych losach i zapożyczeniach z opowieści Lewisa Carrolla, http://magazyn.o.pl/2013/tomasz-marciniak-alicja-wpadla-o-kulturowych-losach-i-zapozyczeniach-ze-slynnej-powiesci-lewis-carroll-rita-baum/ / [dostęp 23.11.2013].

${ }^{12}$ Z. Batko, $Z$ powrotem..., s. 16. 
ujawniając przy tym logiczne uwarunkowania językowej materii. Humor oraz sytuacje komediowe przeplata z poetyckimi i sentymentalnymi fragmentami. To właśnie szczególne poczucie humoru, gra nonsensem i intertekstualne nawiązania stają się dominantą, która buduje pokrewieństwo $\mathrm{z}$ powieścią Carrolla, podobnie jak wykorzystanie ilustracji. $\mathrm{W}$ bajce Batki rysunki Stasysa Eidrigevičiusa są niezwykle ważnym uzupełnieniem literackiej wizji ${ }^{13}$, współtworzą zarówno aurę onirycznej przygody, jak i nostalgii z domieszką surrealistycznego nastroju. Na podstawie tej powieści miał powstać film, wielka szkoda, że nie doszło do jego realizacji.

W opowiadaniu Złote popołudnie Andrzej Sapkowski, by tak rzec, „odwraca kota ogonem”. I to właśnie kot Chester jest tu głównym bohaterem i narratorem, który rozkoszując się błogim spokojem, niespodziewanie spotyka małą idiotkę ${ }^{14}$. Dziewczynka przedstawia się jako Alicja i wyjaśnia, jak się znalazła w Krainie Czarów:

Jestem tu, bo weszłam do króliczej nory. Za białym królikiem o różowych oczach, który miał na sobie kamizelkę. A w kieszonce kamizelki zegarek. [...]

- Paliliśmy trawkę, panienko? - zagadnąłem grzecznie. - Łykaliśmy barbituraniki? Czy może naćpaliśmy się amfetaminki? Ma foi, wcześnie teraz dzieci zaczynają.

- Nie rozumiem ani słowa - pokręciła głową. - Nie pojęłam ani słowa z tego co mówisz, kocie. Ani słóweczka. Ani słówenienieczkaª̨.

Mniej lub bardziej zabawny styl i parodystyczne zacięcie to jeden aspekt tego tekstu (w którym autor m.in. drwi z psychoanalitycznych odczytań opowieści Carrolla), drugi, o wiele ciekawszy i ważniejszy, to interpretacja Krainy Czarów jako Krainy Śmierci ${ }^{16}$. Wizyta Miss Linddell wynika z utraty przytomności wywołanej gorączką (dziewczynka wpadła do zimnej wody podczas wycieczki łódką), co gorsza wypiła truciznę - omyłkowo podano jej laudanum.

W literaturze polskiej, kraina stworzona przez Carrolla jest też traktowana jako pierwowzór alternatywnej, fantastycznej rzeczywistości, w której trzeba walczyć o... tę realną. Tak jest w dwuczęściowej powieści Alicja Jacka Piekary $^{17}$, opisującej związek trzydziestokilkuletniego scenarzysty z czternastolatką. W warstwie językowej sporo tu ironii i niedopowiedzeń, zatem

${ }^{13}$ Autor ilustracji otrzymał główną nagrodę Premi Catalonia d’Illustracio 1986 w Barcelonie na II Międzynarodowym Biennale Ilustracji dla Dzieci.

${ }^{14}$ A. Sapkowski, Złote popołudnie, [w:] Trzynaście kotów. Antologia, Warszawa 1997, sapkowski.pl/module.php?name=News\&file=article\&sid=412 /dostęp: 2014-09-02/.

${ }^{15}$ Tamże.

${ }^{16} \mathrm{~W}$ pierwszej wersji Carroll chciał zatytułować swój utwór Przygody Alicji pod ziemią. Zob. R. Ash, Oryginalna Alicja, [w:] L. Carroll, Alicja w Krainie Czarów, przeł. K. Dworak, Warszawa 2013, s. 187.

${ }^{17}$ J. Piekara, Alicja, Warszawa 2010. 
także kontrowersyjna relacja pozostaje wycieniowana i niedookreślona. Czy to przyjaźń? Czy miłość? Jeśli miłość to platoniczna? W prozie Piekary mit Lolity i oskarżenie: „pedofil” zostają przekonująco zastąpione wieloznacznością oraz tajemniczą magią relacji międzyludzkich, które niełatwo ocenić.

Natomiast wonderland Sylwii Chutnik przewrotnie został zbudowany z najbardziej szarej rzeczywistości i zwyczajnych ludzkich losów. Narratorka tytułowego opowiadania $W$ krainie czarów mówi o sobie: „Jestem jak Alicja. Tylko z deficytem czarów”. Opisuje śmierć dziadka, z którą mimo upływu czasu nie może się pogodzić:

Jak długo to wszystko będzie trwać, prawie dwa lata minęły [...]. Mucha w szklance. Zdziwiona, te gały tak wybałuszone i się dziwię. Ojej, a jak to się mogło stać? Jak to się mogło tak zakończyć? Znowu Alicja stoi bezradnie na środku świata i poprawia fartuszek. Kot-Dziwak ociera się o jej nogę.

- Skąd Kot wie, że jestem stuknięta? [...]

- To oczywiste: inaczej byś tu nie trafita. [...]

- A skąd Kot wie, że sam jest stuknięty?

- Zacznijmy od tego, że pies nie jest stuknięty [...]. Zgadzasz się z takim założeniem?

- Chyba tak - bąknęta Alicja.

- Więc rozumujmy dalej - ciągnęło Kocisko. - Pies warczy, kiedy jest zły, a gdy jest zadowolony, merda ogonem. Ja odwrotnie: warczę, gdy jestem zadowolony, a ogonem merdam, gdy jestem zły. Stąd wniosek, że jestem stuknięty.

Alicja staje się więc kotem. Płacze i wyciera nos ogonem ${ }^{18}$.

Próbka literackiego stylu Chutnik zawiera bezpośrednie cytaty z dzieła Carrolla, ale, co o wiele ważniejsze, bohaterka przywoływanego opowiadania koncentruje się na poszukiwaniu niezwykłości w zwyczajnych sytuacjach: czasem banalnych, a czasem traumatycznych. Takich, które wcześniej czy później każdego spotykają, jak choćby śmierć bliskiej osoby.

\section{Alicja w krainie obrazów}

Alicja... to nie tylko słowotwórstwo i językowe kontaminacje, ale także tekst pobudzający wizualną wyobraźnię, dla której inspiracją były rysunki. Do 1907 roku wyłączność na ilustrowanie baśni Carrolla miał John Tenniel; jego rysunki wyznaczyły kanon przedstawień Alicji - małej blondynki w sukieneczce z falbankami i w fartuszku z dwiema kieszonkami - i zaważyły na obrazowych przedstawieniach literackiego świata pełnego czarów. Wizualne inspiracje trudno jednak ograniczyć jedynie do rysunków czy dzieł plastycznych. Do utworu angielskiego pisarza nawiązywali bowiem twórcy sztuk teatralnych, oper, operetek, musicali, baletów, a nawet pantomimy.

${ }^{18}$ S. Chutnik, W krainie czarów, Kraków 2014, s. 17. Autorka cytuje Carrollowską Alicję w Krainie Czarów w przekładzie J. Kozak (Warszawa 2010, s. 60). 
Szczególną uwagę chciałabym zwrócić na ekranizacje przygód Alicji. Historię dziewczynki, która wyruszyła w podróż po fantastycznej krainie, na duże i małe ekrany przeniesiono ponad czterdzieści razy. Pierwsza adaptacja powstała w 1903 roku, później co klika lat pojawiała się w kulturze nowa, wizualna wersja tej opowieści. Znajdziemy wśród nich adaptacje przeznaczone dla najmłodszych (jak animowana bajka Walta Disneya z 1951 roku), takie, które skrzętnie skrywają niepokojące treści zawarte w oryginale, jak i filmy adresowane do dorosłej widowni (np. pornomusical Buda Townseda z 1976 roku czy surrealistyczny film z roku 1988, Něco z Alenky czeskiego reżysera Jana Švankmajera). Co ciekawe, uniwersum Lewisa Carrolla równie chętnie inspirowali się też autorzy komiksów i gier komputerowych.

Dlaczego filmowcy tak często sięgają po tę opowieść? Ewa Rajewska pisze: „Carrolliańska baśń to zaproszenie [...] do udzielenia sobie prywatnej dyspensy od rzeczywistości po to, by za białym królikiem wskoczyć w głąb prowadzącej nie wiadomo dokąd nory" ${ }^{19}$. Tak! Trzeba to mocno podkreślić! Książka napisana przez Dodgsona wyrasta z tej samej idei co kinematograf: z szarej rzeczywistości porywa nas w Krainę Czarów. Nic dziwnego zatem, iż pierwsza ekranizacja powstała w Wielkiej Brytanii już w kilka lat po wynalezieniu ruchomych fotografii, gdy tylko kino zaczęło swoje próby opowiadania obrazem. Zachowany jedynie we fragmentach film Cecila M. Hepwortha z 1903 roku był jedną z pierwszych produkcji filmowych, w której zastosowano efekty specjalne. Kolejne filmowe wersje powstawały w najróżniejszych rejonach świata, także w Australii, ZSRR i Japonii. Były utrzymane w przeróżnych konwencjach: od komedii, poprzez musical, aż po horror. Ekranizacje układają się w spektrum różnorodnych założeń i koncepcji adaptacji: od utworów poszukujących pełnej zgodności z oryginałem, po „twórcze zdrady” i dzieła swobodnie nawiązujące do powieści. Wśród filmów poświęconych Alicji można znaleźć takie, które wykorzystują strategie transpozycji, transformacji, komentarza, analogii, renarracji, refabularyzacji - za pomocą tych dzieł można zegzemplifikować wszelkie rozwiązania opisane w teoriach adaptacji. Jaki jest kulturowy i egzystencjalny sens różnic w tych realizacjach? Na wybranych przykładach spróbuję odpowiedzieć na to pytanie.

\section{Animowana adaptacja Walta Disneya, czyli błogostan dzieciństwa}

Disnejowska animacja z 1951 roku jest prawdopodobnie najsłynniejszą - czy nawet kanoniczną - adaptacją dzieła Carrolla (odwołania do niej znajdziemy w następnych filmach, szczególnie w wersji z 1999 roku).

${ }^{19}$ E. Rajewska, Dwie wiktoriańskie chwile..., s. 13. 
Popularność nie oznacza jednak, iż twórcom udało się uchwycić wielowarstwowy przekaz pierwowzoru. Oczywiście, patrząc na dzieło Disneya z punktu widzenia dziecka niezaznajomionego z literackim oryginałem, widzimy zupełnie udaną bajkę, której mocną stroną są wartkie tempo narracji i wpadające $\mathrm{w}$ ucho piosenki. Mały widz jest dosłownie unoszony przez pełną zaskakujących zwrotów akcję. W filmie brakuje jednak finezji językowej, za co odpowiedzialna jest zarówno okrojona z trudniejszych elementów gry lingwistycznej adaptacja dialogów, jak i, w polskiej wersji językowej, uproszczenia w tłumaczeniu.

W swojej interpretacji twórcy skupili się na błogostanie dzieciństwa, zapominając, że w wersji literackiej ten czas podszyty jest strachem, a także naznaczony smutkiem nieuchronnego pożegnania z krainą czarów i dziecięcej wyobraźni. Disney zaproponował charakterystyczną dla swego stylu uporządkowaną, wyrazistą kreskę konturów wypełnioną podstawowymi barwami. Pomimo nawiązań w stylu plastycznym i wyglądzie poszczególnych postaci do oryginalnych ilustracji Tenniela zupełnie zaginął niepokój wpisany w jego grafiki. Zwierzaki uzyskały wygląd sympatycznych pluszaków, a cały świat nabrał cech popkultury dla najmłodszych. W przedstawionej fabule kolorowa, ale powierzchowna bajkowość wysuwa się na plan pierwszy. W świecie tym króluje założenie, że w jego granicach nie może się wydarzyć nic złego, opiekuńcze skrzydła bajkowej narracji czuwają nad bohaterką. Symptomatyczna jest scena, w której Alicja zaczyna tonąć w morzu łez - gdy jej łódka ze słoja nabiera wody i zanurza się pod powierzchnię wody - wołanie dziewczynki o ratunek ginie na tle wesołej piosenki. Śpiewają ją zwierzaki, tańczące w koło pośród zalewających wysepkę fal:

Hopla w górę hopla w dół nie ma nic suchszego oprócz najsuchszego z kół [...] tańczyć w kółko to najmilsza rzecz, by nie stracić wątku, więc pamiętaj, że nie ma końca i początku. [...] Gdzie tu kraniec? Krańca nie ma, bo jutro zaczęliśmy taniec, a wczoraj skończmy go. Gonić w koło a wesoło niechaj śpiewa chór, szybkie ruchy będziesz suchy, suchy niczym wiór ${ }^{20}$.

Świat grozy i niebezpieczeństwa nie są brane na serio przez bohaterów kreskówki. Zagrożenie rozbrajane jest przez komizm, to na nim twórcy filmu koncentrują uwagę młodego widza. W tym filmie sytuacje zabawne często budowane są poprzez kontrastowe wykorzystanie relacji między słowami piosenki a obrazem. Wszelkie poważniejsze rozważania, które wiążą się z wątkami filozoficznymi, zostały zatem uproszczone lub pominięte. Nie słyszymy zagadki o tym, co łączy kruka i biurko, tylko taką, która wydała

${ }^{20}$ Cytat na podstawie polskiej ścieżki dźwiękowej animowanego filmu W. Disneya Alicja w Karinie Czarów (1951). 
się twórcom bardziej odpowiednia dla przedszkolnego odbiorcy: „Dlaczego księżyc nie może być niebieski?”21. Zamiast rozmowy o metafizyce czasu, Disney pokazuje świętowanie nieurodzin podczas herbatki u Kapelusznika - pomysł niewątpliwie bliski każdemu dziecku. Skoro urodziny są tylko raz w roku, lepiej obchodzić 364 dni nieurodzin i przyjmować z tej okazji życzenia. W tej scenie bogactwo zmieniających się kolorów i form przedmiotów wykorzystuje możliwości rysunkowej animacji. Widzimy tańczące, gwiżdżące imbryki, wirujące spodki i uśmiechnięte czajniki, które buchają parą w takt muzyki. Świat nasycony radością i beztroską zabawą. Co prawda, gdy pada propozycja, by Alicja napiła się herbaty, szybko okazuje się, że nie jest to takie proste. Niby wystarczy przechylić imbryk, żeby wylały się z niego spodek, filiżanka i sam napój, a herbatę można lać za kołnierz tak, aby wypływała z rękawa wprost do filiżanki, ale mimo tych cudownych możliwości, żadna porcja płynu nie trafia do ust spragnionej dziewczynki. Świat jawi się jako zadziwiający, dzięki łatwości rysunkowej transformacji, ale to jedyny element, który wprowadza nawiązania do onirycznej poetyki Carrolla.

Wonderland w wersji Disneya okazuje się jednowymiarowy - każdemu zdarzeniu towarzyszy dowcip lub slapstickowy gag; trudno przestraszyć się kwiatków, które okazują się niemiłe dla Alicji, nawet chwilowa groza ciemnego lasu zneutralizowana zostaje przez zabawne, wymyślne stworzenia zamieszkujące gęstwinę, zaś okrucieństwa Królowej - przez dowcip Kota i nagle obnażoną bieliznę władczyni. Filmowa animacja nie jest pozbawiona dydaktyzmu: grzeczna i rozsądna Alicja na tle rozbrykanych bohaterów kreskówki, to postać ze wszech miar godna naśladowania. Sielankowa wizja dzieciństwa zdaje się nie wchodzić w żaden konflikt ze światem dorosłych. Sen jest oddzielony od świata realnego, który nawet jeśli bardziej nudny, okazuje się miły i przyjazny dla najmłodszych.

\section{Telewizyjna adaptacja Nicka Willinga, czyli opowieśé pedagokomiczna}

W ekranizacji Alicji w Krainie Czarów z 1999 roku dominuje dążenie, aby zrealizować możliwie najwierniejszą adaptację, zarówno w zachowanej strukturze wydarzeń, jak i wizualnych nawiązaniach do ilustracji Tenniela. Aby podsunąć widzom jeden sposób odczytania fabuły i precyzyjnie wyznaczyć adresata: dziecko w wieku szkolnym, Nick Willing posłużył się ramą narracyjną. W czołówce, na czarnym tle w niewielkim kręgu światła, pojawia się mała postać Alicji oraz wielkie wahadło; jak się okazuje później

${ }^{21}$ Tamże. 
jest to metronom, który wybija rytm, tnąc powietrze niczym topór. Dziewczynka ukazana w przechylonym kadrze zaczyna śpiewać piosenkę - rymowankę Entliczek-pętliczek. Robi to jednak bez przekonania, jakby pod groźbą kary. Pomniejszona postać Alicji wpada w czerń, która okazuje się źrenicą głównej bohaterki. W ten sposób reżyser buduje subiektywizację, proponuje wejście w wewnętrzny świat doznań, emocji i obaw dziewczynki. Alicja nie umie śpiewać. Boi się występu, do którego zmuszają ją dorośli: będą rozczarowani, gdy nie zaśpiewa dla gości zebranych na podwieczorku. Zaprezentowani goście wydają się dziwakami, ich fizjonomie i zachowania staną się podstawą do uruchomienia gry wyobraźni i przekształcenia poszczególnych osób w bohaterów z opowieści Carrolla. Aluzje personalne stały się główną osią konstrukcji bohaterów. Twórcy proponują satyrę na wiktoriańską obyczajowość. Trudne relacje dziecko - dorośli odczytać można jako efekt pedagogicznych metod, które już odeszły do lamusa. Oto kwestia wygłoszona przez Pana Mysz - wykładowcę: „Moje wykłady trzeba zobaczyć i usłyszeć, żeby je przecenić. Oczywiście zdania są podzielone. Ostatnio cała publiczność syczała... Oprócz jednego. On przyklaskiwał... syczeniu. Wykładam rzeczy znane. Najlepiej jak potrafię. Ciągle to samo zdanie”. I słyszymy najbardziej „suchy” wykład historii o Wilhelmie Zdobywcy. Współczesne dzieci mogą odetchnąć z ulgą, dziś jednak trochę zmieniły się metody dydaktyczne. Czy jednak przymus szkolny nie pozostaje przymusem i ograniczeniem dziecięcej wyobraźni?

Zastanówmy się nad interpretacją filmu. Podobieństwa między światem snu i jawy nie budzą niepokoju. Kraina Czarów traci swój niebezpieczny status, staje się rodzajem terapii dla dziewczynki, która dzięki niej spostrzega, że dorośli nie są straszni, ale śmieszni. Po lekcjach z Nibyżółwiem dziewczynka potrafi pokonać tremę i śmiało występuje przed zgromadzoną publicznością. Śpiewa homadryla, którego nauczyła się od nowych przyjaciół i zbiera pochwały od zgromadzonych ${ }^{22}$. Po tej „oczyszczonej” z wszelkich wieloznaczności adaptacji niewiele pozostaje w pamięci. No, może tylko uśmiech Whoopi Goldberg w roli Kota z Cheshire.

${ }^{22} \mathrm{~W}$ polskiej wersji językowej tego filmu otrzymujemy przekład daleki od doskonałości; tłumaczenie dosłowne, przypadkowe, bez jakiejkolwiek finezji, co niszczy zabawną wymowę oryginału. Gdy Nibyżółw opowiada o swojej szkole, słyszymy następującą wypowiedź: „Uczył nas szywania, pisania, podstaw arytmetyki: ambicji, destrukcji. I uczyliśmy się też cedzenia. Nauczyciel cedzenia to był stary węgorz. Uczył nas cedzenia i rozciągania, i spiralowania” Dla porównania w tłumaczeniu Słomczyńskiego program szkolny wygląda następująco: „Na początku była oczywiście nauka Chlapecadła i Portografia [...] później różne odgałęzienia Arytmetyki - Wodowanie, Obejmowanie, Dnożenie i Przydzielenie [...]. Cóż była jeszcze Histeria [...] starożytna i nowożytna, Oceanografia i Rybunki... Nauczycielem Rybunków był stary węgorz morski [...]. Uczył nas Rybunków i Falowania” (cyt. za: E. Rajewska, Dwie wiktoriańskie chwile..., s. 72.). Posługując się takim językiem, postać Nibyżółwia, grana przez skądinąd świetnego komediowego aktora Gene Wildera, wypada dość żałośnie i po prostu mało śmiesznie. 


\section{Coś z Alicji Jana Švankmajera, czyli Alicja w krainie zapomnianych lalek}

Pisząc o adaptacjach Alicji, trudno znaleźć film bardziej kontrastujący z Disnejowską wersją niż Něco z Alenky (1988) czeskiego wirtuoza animacji poklatkowej, Jana Švankmajera. Gdy oglądamy jego dzieło, mamy wrażenie, że wraz z bohaterką wpadliśmy do Krainy Koszmarów. Już sama podróż „w głąb króliczej nory” jest w stanie zmrozić widzowi krew w żyłach - obserwujemy dziewczynkę, uwięzioną w ciasnej, trzeszczącej ciemnej windzie i zastanawiamy się, czy nie jest to przypadkiem winda do piekła. Podążając w dół, Alicja mija półki wypełnione lalkami oraz przetworami, ale $\mathrm{w}$ słoikach, zamiast pomarańczowej marmolady, kryją się zatopione $\mathrm{w}$ formalinie martwe zwierzęta oraz ich szkielety.

Obraz Švankmajera jest wyjątkowy wśród filmowych adaptacji książki Carrolla, gdyż - według mnie - jako jedyny oddaje wrażenie wszechobecnego oniryzmu i niepokoju, wypełniających karty Alicji w Krainie Czarów. Podobnie jak w dziele literackim, jedyną logiką obecną w filmie jest logika snu, pozwalająca bohaterce w jednej chwili z mrocznej sypialni wybiec na martwe, kamieniste pole, na którym w oddali czeka już biurko wypełnione starymi przyrządami arytmetycznymi - jego szuflada jest surrealistyczną alegorią króliczej nory. Znacząca jest zresztą sama scena wejścia do szuflady: przy pierwszej próbie bohaterka kaleczy się jednym z przyrządów, kamera zaś ukazuje zbliżenie na jej krwawiący palec. Jednocześnie widz otrzymuje zapowiedź tego, z jakiego rodzaju Krainą Czarów będzie miał do czynienia: to miejsce, w którym można fizycznie cierpieć, krwawić, a nawet ponieść śmierć.

Wykreowany przez Švankmajera świat wygląda obskurnie i odpychająco, wypełnia go okrucieństwo i przyczajona groza. To kraina podziemna: piwnic, komórek, schowków lub porzuconych pokoi o odrapanych ścianach i ciemnych strychów obwieszony suszącą się bielizną. Biel wielkich płacht poszewek i obrusów kojarzy się z duchami powieszonymi na sznurach. Nie ma w tej krainie nawet śladu po cudowności kolorowego miejsca pełnego mówiących kwiatów. Z ekranu niemal czujemy zapach stęchlizny i zaduch zakurzonych pomieszczeń. Nie znaczy to jednak, że ta „druga strona” jest mniej magiczna czy intrygująca. Bohaterka jest samotnym dzieckiem, które się nudzi. W nieskończoność przemierza opustoszałe pokoje, pozbawione okien i pełne potrzaskanych mebli - przede wszystkim biurek. W ich szufladach kryje się większość przedmiotów koniecznych do poruszania się po Krainie Czarów: ciastka bądź butelki napoju zmieniającego wzrost, których zawartość do złudzenia przypomina atrament; nie ma jednak na nich zachęcających napisów: „wypij mnie”.

W wizji reżysera dziewczynka nie bawi się zwykłymi zabawkami większość bajkowych bohaterów zbudowana została z wypreparowanych 
martwych zwierząt bądź ich szkieletów i wprawiona w ruch techniką animacji poklatkowej. Sama Alicja po zmniejszeniu zamienia się w zniszczoną, starą lalkę. Gdy rośnie, kukła powiększa się wraz z nią, przez co staje się więzieniem dla żywej dziewczynki. W tej surrealistycznej wizji ograniczenia i normy nie są sprowadzone do wiktoriańskiego gorsetu i nakazu dygania. Historyczny kontekst bajki Carrolla został pominięty, po to by wyeksponować symbol lalki i manekina - martwych za życia dorosłych. Ten zabieg budzi skojarzenia z Schulzowskim traktatem, w którym uwięzieni w pałubach ludzie wyją, chcąc się z nich wydostać, ale ich głosy nie są słyszane. Świat koszmarnych na pół umarłych stworzeń groteskowo wyolbrzymia zasady świata realnego. W filmowych postaciach możemy odnaleźć krytyczny obraz ludzi dorosłych: wiecznie zagonionych, wiecznie spóźnionych, biegających tam i z powrotem. Echa odwołań do „prawdziwego życia” odnajdujemy w scenie, gdy Alicja obserwuje awanturę w małym domku dla lalek. Rzucane talerze i garnki wypadają przez drzwi i okna. Porcelanowe i szklane odłamki stanowią zagrożenie i boleśnie ranią dziewczynkę. Zabawa w kłótnię? Cały domek dla lalek trzęsie się podczas rozbijania sprzętów i kuchennej zastawy, dźwiękom tym towarzyszy przeszywający, niekończący się płacz dziecka.

W wizualnym opracowaniu Czegoś z Alicji można się dopatrzeć celowego kontrastu z kolorowymi często przesłodzonymi, niebiesko-różowymi kadrami filmu Disneya. W obrazie czeskiego artysty dominuje ciemna, ponura kolorystyka z przewagą czerni, brązów, zgniłych zieleni i szarości, filmowanych w niskim kluczu oświetleniowym. Mała Alicja nasyca swoją wyobraźnię okrucieństwem i mrokiem, które stanowią dominantę nastroju wszystkich wydarzeń. Iwona Hałgas cytuje słowa reżysera: „Nikt nie potrafi być równie okrutny jak dziecko” ${ }^{23}$. Można zapytać, co było pierwsze: okrutne dzieci, czy okrutni dorośli? Według artysty nie istnieje pojęcie niewinnego dzieciństwa, co dobitnie przedstawia końcowa scena przebudzenia Alicji z koszmaru - widzimy wówczas, że świat rzeczywisty otaczający dziewczynkę jest równie szary i przygnębiający, a zarazem przenikają do niego elementy fantastyczne z minionego snu: ukryta w grządce kwiatów szuflada skrywa w sobie nożyce, takie same, jakimi Biały Królik na rozkaz królowej ściął głowy Kapelusznikowi i Marcowemu Zającowi. Najbardziej zatrważająca jest jednak końcowa kwestia Alicji, która beznamiętnym tonem mówi: „spóźnia się... myślę, że utnę mu głowę". Reżyser zdaje się zadawać widzowi pytanie: a może Królowa Kier ze swą żądzą mordu jest jedynie odzwierciedleniem ukrytych pragnień pozornie niewinnego dziecka?

${ }^{23}$ I. Hałgas, Alicja $w$ Krainie Lalek, „Przegląd” 2010, nr 15, http://www.przeglad-tygodnik.pl/pl/artykul/alicja-krainie-lalek [dostęp 19.10.2014]. 


\section{Alice in the Wonderland, czyli Burton w sklepie Disneya}

Zrealizowana w 2010 roku kolejna adaptacja została wyreżyserowana przez słynnego ekscentryka i melancholika Hollywood - Tima Burtona. Zdawać by się mogło, iż Burton, wielki fan twórczości Carrolla, będzie twórcą zdolnym przedstawić wielowymiarowość Alicji w Krainie Czarów. Tym bardziej, iż reżyser często poświęcał uwagę bohaterom o skomplikowanej psychice, w której świat urojony miesza się z rzeczywistym. Każdy, kto zna wcześniejsze dokonania artysty, jak choćby Gnijąca Panna Młoda, Sok z żuka czy Edward Nożycoręki, oczekiwał, że typowe dla jego stylu zabiegi w kreowaniu niezwykłych światów wszechobecna groteska czy silne nawiązania do ekspresjonizmu - będą nieodzownymi elementami także tej wizji.

Trzeba jednak pamiętać, iż film Alice in the Wonderland odnawiał współpracę artysty ze Studiem Disneya - a to niestety oznaczało, iż dzieło zostanie poddane presji producentów i „przykrojone” do gustu familijnej publiczności. W konsekwencji Burton zaprezentował widzom kontynuację wizji Disnejowskiej, choć wskazywał na inspiracje filmem Švankmajera i poetyką surrealistyczną. Wprowadzona rama narracyjna ogranicza możliwości interpretacyjne - Alicja jako już prawie dorosła panna ucieka do króliczej nory wprost ze swego przyjęcia zaręczynowego. Gdy powróci do świata realnego, będzie zdolna do przeciwstawienia się konwenansom i samodzielnego decydowania o sobie. Tymczasem okazuje się, że Kraina Czarów zmieniła się od jej ostatniej wizyty (dziewczyna zapomniała, że kiedykolwiek tu była). Pod rządami królowej Kier, zwaśnionej ze swą siostrą - Białą Królową (zainspirowaną postacią królowej Szachów z drugiej części książkowych przygód Alicji), szerzy się terror. Okrutne metody królowej doprowadziły do zgładzenia lub uwięzienia wielu mieszkańców, a tych pozostałych na wolności zmusiły do spiskowania przeciwko władczyni i jej polityce. Czy jednak Biała Królowa musi być tak nieskazitelnie dobra? Jednoznaczność postaci nie wzbogaca interpretacji, ale ją ogranicza. W rezultacie film okazuje się dość swobodnym nawiązaniem do literackiego oryginału. Doskonale znane widzom postaci stają się pretekstem do opowiedzenia zupełnie nowej historii, podczas której Alicja musi pokonać Żaberzwłoka (Jabberwocka) - legendarnego potwora będącego najsilniejszą „bronią" Królowej Kier.

Świat snu wykreowany w tym filmie nie jest, co prawda, całkowicie sielankową krainą znaną z wcześniejszej o pół wieku animacji, spowijają go bowiem tajemnicze mgły, a niebo jest niemal zawsze burzowe, ale brakuje w nim elementów groteski obecnych w stylistyce 
wcześniejszych Burtonowskich filmów. Co więcej, przedstawiona kraina mimo wizualnego bogactwa pokazywana jest w sposób dość monotonny - bohaterka podróżuje przez ponure pola bądź mroczny las przyczepiona do kapelusza lub na grzbiecie psa. Długie jazdy kamery uzasadnia chęć wykorzystania technologii 3D, ale te same obrazy oglądane na płaskim ekranie tracą siłę ekspresji i stają się po prostu nudne. Trudno zrozumieć, dlaczego Alicja musi przebywać długą drogę przez pola. Czy w świecie stworzonym przez Carrolla nie wystarczyłoby otworzyć tajemnicze drzwiczki i przejść przez nie do wybranego dowolnie miejsca? Pod względem kreacji „dziwów” Burton jakby nie podołał zadaniu. Pozostawił niedosyt. Nie zaskoczył tak, jak potrafił wcześniej zaskoczyć swoich widzów.

$\mathrm{Na}$ uwagę zasługuje strona językowa filmu, tekst oryginału został bowiem uwspółcześniony ${ }^{24}$. W dialogach wykorzystano gry językowe, zaskakujące związki frazeologiczne, wprowadzono nowe słowa-walizki, nawiązując jedynie do literackiego stylu Carrolla. Niektóre wyrażenia okazały się na tyle ciekawe i zabawne, że powiedzonka z filmu weszły do młodzieżowego żargonu. Czerwona Królowa mówi do swego oblubieńca na powitanie: „Skazeuszu, witaj, ty łotrze. Co u ciebie złego?” Mniamałyga, gdy wścieka się na szczerzącego się Kota z Cheshire, wybucha ze złością: „Kocie, ty psie!”.

W galerii Burtonowskich postaci najciekawszą pozostaje Szalony Kapelusznik. Kreacja aktorska Johna Deppa wydobywa zarówno szaleństwo, jak i filozoficzną naturę tego bohatera: „Bo ja uważam, że czas powinien wszystko zapomnieć i wybaczyć albo wybaczyć i zapomnieć. Kolejność nieobowiązkowa, a nawet śmiem twierdzić dowolna”.

Filmowa kraina Burtona zawiera, rzecz jasna, elementy, które warto zapamiętać także ze względu na stronę plastyczną. Jedną z najbardziej interesujących scen pod względem wizualnym jest upadek Alicji w głąb króliczej nory - jest to też jedyny moment w filmie, gdy prawa fizyczne w Krainie Czarów zostają zawieszone. Na przykład podłoga, na której ląduje Alicja, okazuje się sufitem. Uznanie budzi także pełna grozy, wręcz postapokaliptyczna sceneria słynnej herbatki u Kapelusznika, wyprawionej na bagnach w cieniu spalonego młyna. Bardzo atrakcyjnie przedstawione zostały również pałace obu królowych - projekty scenograficzne dopracowane są w najdrobniejszych detalach. Zamek Królowej Kier otacza fosa pełna wody i uciętych przez władczynię głów. Scena, gdy pomniejszona Alicja, przeprawiając się przez fosę, stawia stopy na pływających po wodzie głowach, to chwilowy powrót do tego, za co można podziwiać kino Tima Burtona.

${ }^{24}$ Dialogi w tłumaczeniu Kuby Wecsile wykorzystują skojarzenia i wieloznaczne gry, jakie oferuje język polski. 


\section{American McGee's Alice oraz Alice: Madness Returns, czyli w krainie gier}

Oglądając Alicję Burtona, trudno powstrzymać się od porównania jej $\mathrm{z}$ serią gier komputerowych - American McGee's Alice oraz Alice: Madness Returns $^{25}$. Zarówno w wersji Burtona, jak i w American McGee wykorzystany został pomysł powrotu Alicji po latach do Krainy Czarów i skonfrontowanie wyobraźni dziecka z dorosłą osobowością. W obu przypadkach upływ czasu, jaki minął od dnia pierwszej wizyty Alicji, odcisnął silne piętno na Krainie Czarów, rządzonej przez okrutną Królową Kier. Jednak tylko w American McGee’s Alice metamorfoza krainy ma związek z psychiką głównej bohaterki - dziewczyna wpada w stan katatonii po tragicznym pożarze domu, w którym zginęła cała jej rodzina. Ogarnięta wyrzutami sumienia powraca do Krainy Dziwów, by odkryć, że zmieniła się ona nie do poznania - wszystko, co znała wcześniej, stało się nagle bardziej wynaturzone i groteskowe. Okrucieństwo Królowej Kier - które okazuje się ucieleśnieniem rozpaczy i lęków samej Alicji, niezdolnej do zaakceptowania prawdy - pogrąża całą, piękną niegdyś krainę w mroku. Wpływa również negatywnie na serca i umysły jej mieszkańców, czyniąc ich jeszcze bardziej karykaturalnymi i niebezpiecznymi. Misja Alicji, aby pokonać Królową, to szukanie ratunku nie tylko dla fantastycznej krainy, ale przede wszystkim dla własnego umysłu.

To właśnie w grach zostały najpełniej wydobyte wszystkie mroczne elementy tkwiące w opowieści Carrolla. Przy czym podkreślić trzeba, iż sam produkt nie jest skierowany do dzieci, adresatem jest dorosły odbiorca. Twórcy nie banalizują świata psychiki, tylko wskazują na ciemne moce wyobraźni - różnego rodzaju manie, stany lękowe, fobie. Alicja z utworu pisarza jest jeszcze małą niewinną dziewczynką, jednak jej wyobraźnia kreuje już obrazy okrucieństwa. Gry z tej serii zdają się pokazywać, jak może przekształcić się dziecięca Kraina Czarów, a więc po prostu dziecięca wyobraźnia, pod wpływem „dorosłych” doświadczeń - przeżytej traumy, spotkania ze śmiercią. To szokujące spotkanie z Realnym, w jego najbardziej drastycznym wymiarze, odpowiedzialne jest za załamanie psychiki. Bogactwo wizualne świata przedstawionego urzeka, choć nie jest to ugrzeczniona „ładność" dziecięcych marzeń. Interaktywna formuła gry pozwala do woli eksplorować Krainę Czarów (która zdaje się bardziej odzwierciedlać koszmarny sen szaleńca niż marzenia dziewczynki czy młodej dziewczyny). Zanurzenia takiego nie zaoferował widzowi żaden $\mathrm{z}$ dotychczasowych filmów. Gracz-Alicja godzinami może przemierzać kolejne poziomy, które

${ }^{25}$ Dziękuję w tym miejscu mojej studentce - Annie Sobolewskiej, za jej interesującą analizę filmoznawczą, szczególnie zaś za inspirację i zainteresowanie grami American McGee’s Alice oraz Alice: Madness Returns, które stały się podstawą tej części artykułu. 
zaskakują oryginalnością, (np. Card Castles in the Sky z drugiej części). Akcja rozgrywa się wśród unoszących się wysoko ponad ziemią bajecznych karcianych zamków, zjeżdżalni oraz ścieżek, które wciąż same się układają i od nowa budują. Pomimo jego niezaprzeczalnej urody i czaru, nie ulega wątpliwości, że jest to świat makabryczny, pełen grozy i okrucieństwa.

Obie przywołane tu gry można traktować jako jedną fabularną całość. Jednak różnią się one znacząco w przedstawieniu wyobrażonego świata, co jest uwarunkowane zmieniającą się kondycją psychiczną bohaterki. Świat w pierwszej części gry obrazuje tragiczny stan Alicji z okresu jej pobytu w szpitalu dla psychicznie chorych - w tej części dominuje depresyjna aura otoczenia, przygaszone kolory, dziwaczne, budzące grozę elementy krajobrazu. Poczucie wszechogarniającego lęku i beznadziei pogłębione zostaje przez przepiękną, lecz niezwykle mroczną i melancholijną ścieżkę dźwiękową autorstwa Chrisa Vrenny, znanego m.in. ze współpracy z Marylinem Mansonem. Delikatne, a jednocześnie złowrogie melodie pozytywki czy odgłosy pobrzękujących filiżanek (Taking Tea in Dreamland) przeplatają się z „płaczliwymi” partiami skrzypiec, odgłosami warczących zwierząt czy ludzkim szlochem (Pool of Tears). Razem ścieżka audialna tworzy wyjątkowo niepokojącą całość i oddaje złożony, wieloznaczny charakter świata stworzonego przez McGee.

Kraina Czarów wykreowana w drugiej części gry nie jest już tak bezwzględnie smutna i przerażająca. Istotny wpływ ma tutaj poprawiająca się kondycja psychiczna Alicji. Gdy jej depresja zostaje wyleczona odsłania się nowe, bardziej pogodne oblicze Krainy Czarów. Pierwszym miejscem w Alice: Madness Returns, do którego trafia bohaterka po przeniesieniu się do fantastycznego świata, jest Dolina Łez (z posągiem płaczącej Alicji). Dolina wygląda tu niczym ogród, w którym rosną różnokolorowe, niezwykłe kwiaty i latają zachwycające owady, a wśród nich najpiękniejsze, oszałamiające swoją urodą motyle. Tylko uważni fani są w stanie zorientować się, że dolina pojawiła się już w pierwszej części gry - wówczas jednak bardziej przypominała osnute mgłą mroczne bagnisko, pełne monstrualnych rozmiarów owadów, które widziane z perspektywy pomniejszonej eliksirem Alicji były groźne i budziły strach. Kolejne poziomy gry stają się stopniowo coraz mroczniejsze i dziwniejsze, równolegle do tego, jak „rzeczywista Alicja” na powrót pogrąża się $\mathrm{w}$ depresyjnym stanie i ponownie wymaga leczenia psychiatrycznego. W drugiej części gry rozgrywka nie ogranicza się wyłącznie do obszaru Krainy Czarów, poznajemy tutaj także rzeczywiste życie Alicji w Londynie, odkrywając wiele oczywistych analogii pomiędzy światem realnym i zmyślonym. W miarę jak stan psychiki bohaterki ponownie się pogarsza, elementy świata realnego i fantazmatycznego zaczynają się z sobą niebezpiecznie przeplatać. Najlepiej zostało to przedstawione w rozgrywce ze szpitala psychiatrycznego. Sceneria bardziej przypomina filmy z gatunku gore niż bajkę dla dzieci. Wychudzona i ogolona na łyso Alicja, odziana 
w kaftan bezpieczeństwa, niezgrabnie podąża ku wyjściu. Droga do niego prowadzi przez labirynty korytarzy i sale szpitalne, wyglądające jak miejsca tortur (wrażenie to potęgują plamy krwi na posadzce oraz przerywniki filmowe, ukazujące zatrważające procedury „medyczne”). Kraina Szaleństwa rzutuje na rzeczywisty świat; spotkane przez Alicję postaci - dwaj skłonni do okrucieństwa pielęgniarze - mają swe odpowiedniki w postaciach literackich Tweedle-Dee i Tweedle-Duma. Ich wizerunki „odbijają się” na suficie niby pozorny obraz „po drugiej stronie lustra”.

Przeplatanie różnych wymiarów rzeczywistości, ukazanie Krainy Czarów i Krainy Szaleństwa jako miejsc sąsiadujących, w których zanurza się naprzemiennie Alicja-gracz to najciekawsze doświadczenie wyniesione z opisanych gier. Fabularne rozwiązania, choć nawiązują do oryginału Carrolla, stanowią bardziej komentarz niż właściwą adaptację. Twórcom gier udało się uchwycić wieloznaczność losów głównej bohaterki, a jednocześnie wykorzystać dramaturgiczną siłę subiektywizacji, charakterystyczną dla narracji gry komputerowej.

\section{Podsumowanie}

Można odnieść wrażenie, że dzieło Carrolla jest niewyczerpywalne, zarówno pod względem językowym, jak i wizualnym. Jego otwartość i wieloznaczność okazuje się nieustannym zaproszeniem do powrotów. Kraina Czarów inspiruje, kusi, aby się w niej odnaleźć, skłania do poszukiwania wciąż nowych interpretacji. Z jednej strony wydaje się, iż Alicja zarówno w krainie słów, jak i w krainie obrazów czuje się całkiem dobrze. Nie grozi jej zapomnienie. $\mathrm{Z}$ drugiej jednak - dotychczasowe prze-pisania utworu, szczególnie adaptacje filmowe, pozostawiają niedosyt. Alicja wciąż czeka, aby artysta porwał ją i widzów w taką Krainę, która będzie zapierać dech w piersiach: będzie zabawna, ale i straszna, pełna grozy, ale i melancholii, bogata w kalambury i żarty językowe, ale także pytania filozoficzne. A wszystko niech dzieje się lekko i z gracją... nawet, jeśli spadamy w głąb króliczej nory.

\section{Alice in lands of words and images}

\section{Summary}

Alice followed the rabbit down the rabbit-hole, without thinking about how she was going to get out... Alice and her Wonderland falls in our audiovisual culture and nobody is thinking that she was going to get 
out. Alice's adventures in words and images seem to be a never ending story. Lewis Carroll's book is one of the most popular texts, which is rewritten in different medias. Literature, movies, computer games are inspirited by his special fairytale dedicated not only for children but for adults, too. This article refers to a few main tendencies in rewriting Alice's Adventures in audiovisual texts and considers their components. The author compares different images and interpretations in movies by Walt Disney, Nick Willing, Jan Švankmajer and Tim Burton. It may be noted that in author's opinion computer games: American McGee's Alice and Alice: Madness Returns not only reconstructed but also intensified a very important relationship between real and virtual life, between sanity and insanity and they do it a better way than the film medium. At the same time high expectations for screening could be inspiring to look for and wait for a new creation of Wonderland in a future cinema. 